\title{
55. Effects of Gamma-Irradiation on the Histogenetic Aggregation of Dissociated Cells from Chick Embryos (Preliminary Report)
}

\author{
By Yuh H. NAKanishi,*) Hatao Kato,*) Tamiko \\ IWASAKI*) and Tohru OKIGAKI**) \\ (Comm. by Yoshimaro TANAKA, M.J.A., April 12, 1963)
}

Recently, a new technique has been developed by Moscona (1961a) to produce histogenetic aggregates with the aid of a gyratory shaker from dissociated embryonic chick or mouse cells in vitro under controllable and standardizable conditions. Utilizing this technique several investigations have heen undertaken with interesting results in attempts to understand the mechanism of histogenetic cohesion of dissociated cells (Moscona 1961 b, c, 1962, Steinberg 1962a, b, c, d, Kuroda 1962).

The present paper describes briefly the effects of gamma-irradiation on the histogenetic aggregation of dissociated embryonic chick cells, in a hope to obtain some preliminary information on the cellaggregation mechanism under the influence of radiation or chemicals which would modify the cellular metabolism.

Material and methods. Six-day chick embryos were selected as material for this study. The whole body after removal of the head was washed with three changes of Rinaldini's physiological salt solution. The bodies were then transferred to a watch glass with a small amount of $0.2 \%$ trypsin solution dissolved in Rinaldini's solution and cut into shreds with scissors. The shreds were suspended in trypsin solution, approximately 10 times in volume, and stirred at $37^{\circ} \mathrm{C}$ for 20 minutes with the aid of a magnetic stirrer. Then an equal amount of culture medium was added to the tissue suspension thus obtained. The tissue was dispersed into single cells by flushing them briskly, use being made of a $20 \mathrm{ml}$ syringe fitted with a needle (1.5 mm inner diameter). After having been centrifuged at $3000 \mathrm{rpm}$ for 15 minutes, the sediments were washed with three changes of the culture medium, and finally re-suspended in the medium, with adjustment to $10^{7}$ cells per $\mathrm{ml}$ through microscopical examinations. The culture medium used for cultivation was prepared after Horikawa's formula (1961, see Table I). The cell suspension thus prepared was dispensed into test tubes and irradiated with gamma-rays from a cobalt ${ }^{60}$ source $(3000 \mathrm{c}$ ) at doses of $500 \mathrm{r}, 1000 \mathrm{r}, 1500 \mathrm{r}, 2000 \mathrm{r}$,

*) National Institute of Radiological Sciences, Chiba.

**) Biology Department, International Christian University, Mitaka, Tokyo. 
Table I. Components of the culture medium

\begin{tabular}{lr}
\hline Hanks balanced salt solution & $1 \mathrm{l}$ \\
Yeast extract & $1.0 \mathrm{~g}$ \\
Lactoalbumin hydrolysate & $5.0 \mathrm{~g}$ \\
Glucose & $4.5 \mathrm{~g}$ \\
Streptomycin & $100 \mathrm{mg}$ \\
Penicillin & $100,000 \mathrm{unit}$ \\
$\mathrm{NaHCO}_{3}$ & $0.8 \mathrm{~g}$ \\
Phenol red & $0.02 \mathrm{~g}$ \\
Inactivated bovine serum & $200 \mathrm{ml}$ \\
\hline
\end{tabular}

$2500 \mathrm{r}, 5000 \mathrm{r}, 10,000 \mathrm{r}, 15,000 \mathrm{r}$ and $20,000 \mathrm{r}$, with the dose-rate of $200 \mathrm{r}$ per minute. After irradiation, $1.5 \mathrm{ml}$ of the cell suspension from each group were transferred to $10 \mathrm{ml}$ Erlenmeyer flasks. The flasks were horizontally rotated on a platform of a gyratory shaker with a $3 / 4$ inch eccentric rotary motion at a constant speed of $60 \mathrm{rpm}$ at $37^{\circ} \mathrm{C}$. At the end of twenty-four hours, the number of free cells remained in the medium, as well as the number and diameter of cell-aggregates were scored. The free cells immediately before and after cultivation were squashed with acetic dahlia for cytological observations. Further the aggregates were fixed with Bouin's fluid for histological observations. Sections, 7 micra in thickness, were made through the ordinary paraffin method. Mayer's hemalum and Mallory's triple stain were the stains employed. The data in this paper were based on the investigation of 200 flask cultures derived from 265 embryos.

Results of experiments. After one to 2 hours of cultivation, numerous small clusters, visible to the naked eye, were present in both non-irradiated and irradiated cultures. With the lapse of time, those clusters increased in size by accretion of free cells. By 24 hours, about 80 rounded and oblong aggregates with bumpy surface, 0.1 to $1.0 \mathrm{~mm}$ in diameter being $0.3 \mathrm{~mm}$ on the average, were observed in each flask of non-irradiated cells and of cells irradiated at $500 \mathrm{r}$ to $15,000 \mathrm{r}$. On the other hand, dissociated cells irradiated at 20,000 r produced smaller aggregates than those irradiated at other dosages, or minute clusters. In control cultures as well as in those irradiated at $500 \mathrm{r}$ to $15,000 \mathrm{r}$, about $6.7 \times 10^{6}$ cells per $\mathrm{ml}$ always remained discreted being free in the medium, while in cultures irradiated at $20,000 \mathrm{r}$ about $8.6 \times 10^{6}$ cells remained free. Microscopical observations on squashed preparations revealed that abnormal cells characterized by pycnotic or fragmented nuclei and nuclei showing unusual chromatin coagulation increased in number gradually with the increase of doses.

It was seen in sections through the aggregates that there were 
certain histotypic groups of cells together with cells scattered in the intercellular substance (Fig. 1). Those groups were formed by selective sorting out of cells according to their specific type. Cells forming the histotypic groups in the aggregates may be described in outline as follows:

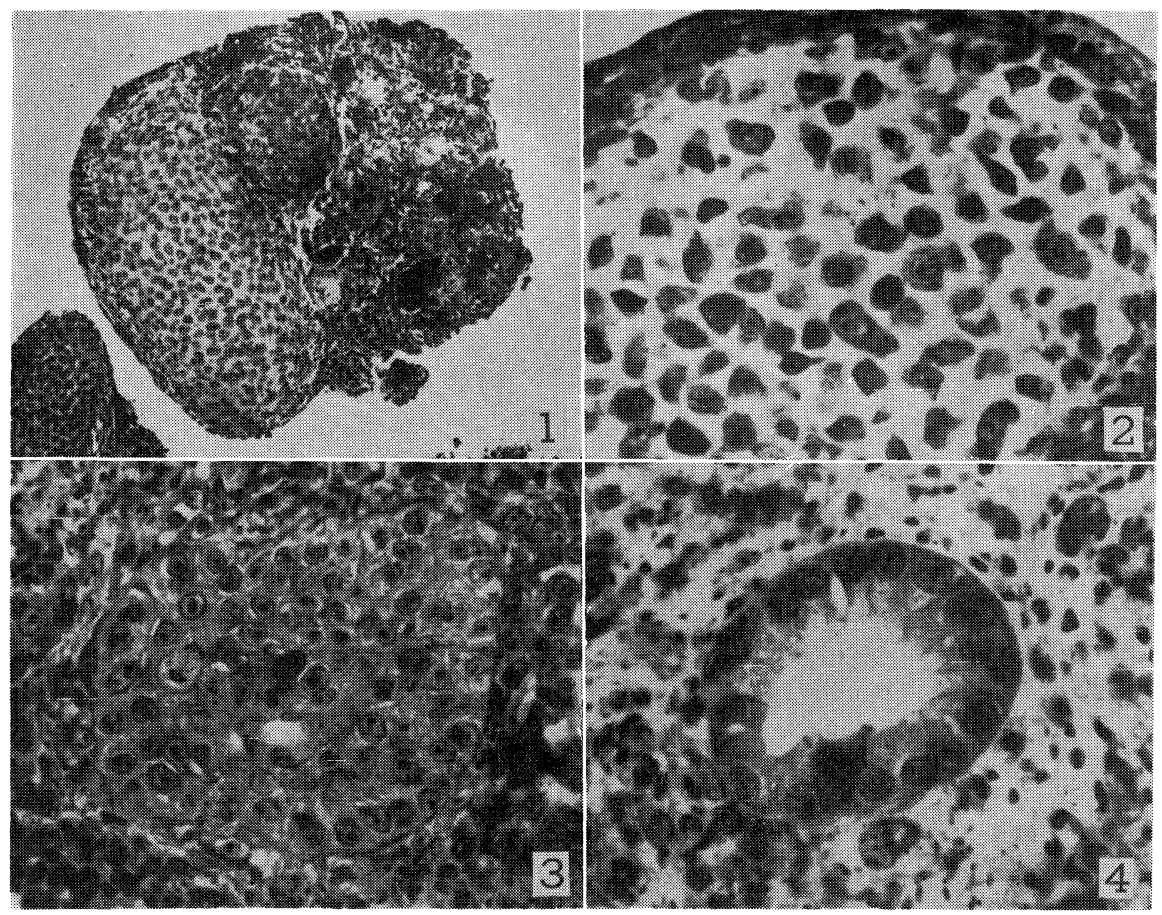

Figs. 1-4. Internal architecture of aggregates at 24-hour culture, formed by dissociated cells from the whole bodies of 6-day chick embryos after removal of heads. Fig. 1. Selective groupings and histotypic differentiation of cells. $\times 100$. Fig. 2. Cells are dispersed in the interstitial substance, resembling cartilage. $\times 400$. Fig. 3. Cells are compactly associated, adhering closely one to another. $\times 400$. Fig. 4 . One layer of columnar cells forms a tubular structure. $\times 600$.

(1) Cells with large-sized nuclei were dispersed in the interstitial substance. Those cells, resemblant in appearance to cartilage, were sharply demarcated from the surrounding tissues by several layers of densely packed, elongated cells (Fig. 2). Their nuclei contained one or two distinct nucleoli, with the cytoplasm extended into processes being connected with the interstitial substance of a fibrous network. (2) Large-sized cells were compactly associated with each other (Fig. 3). They were not covered by any peculiar layer of cells. The spherical nuclei contained one, rarely two, distinct nucleoli. (3) Columnar cells formed tubular and vesicular structures of one layer (Fig. 4). Considered from their structural features, they may 
possibly be mainly of mesonephros origin. Some of the vesicles showed a homogeneous colloid-like substance, probably of a secretory nature, being stained with anilin blue. The distribution and proportion of those cells within the aggregates varied considerably without particular relation to the size of the aggregates. It is thus evident that the results of the present experiments with dissociated cells from chick embryos supplement similar features reported by Moscona (1961a, 1962) and by Steinberg (1962 b, c, d). Further details of the internal architecture of aggregates are subjects of further investigation now in progress.

There was no remarkable difference in internal architecture between aggregates produced by non-irradiated cells and irradiated ones. The cells forming the aggregates seemed to be quite healthy in general features with a considerable number of mitotic cells.

Remarks. Moscona $(1961 \mathrm{~b}, 1962)$ reported that embryonic chick cells showed no aggregation at a low temperature such as $15^{\circ} \mathrm{C}$, and that the cohesion of cells might depend on metabolic activities which at this temperature were slowed down to an ineffective rate, or completely stopped, or perhaps differentially modified. It is well known that irradiation reduces cellular activities to a considerable degree. In the present experiments, however, the number, size, shape and internal architecture of aggregates produced by irradiated cells were remarkably similar to those of non-irradiated controls, except that aggregates produced by cells which received $20,000 \mathrm{r}$ decreased in size with an increase in number. Though the data at hand are insufficient for evaluation of the evidence, it seems to the authors on the basis of observed facts, that aggregation as well as typespecific sorting out of dissociated cells into separate groupings depends on a factor or factors which are not primarily affected by irradiation, so far as the scope of the present experiments is concerned.

The authors are deeply indebted to Dr. Yoshio Nakao, Head of the Divisions of Biology, and Genetics of this Institute, for his inspiration and keen interest in the subject. Further cordial thanks are extended to Professor Sajiro Makino, Hokkaido University, for going through this manuscript with helpful suggestions.

\section{References}

Horikawa, M. (1961): Jap. Jour. Genet., 36, 319-336.

Kuroda, Y. (1962): Jap. Jour. Genet., 37, 396.

Moscona, A. (1961a): Exptl. Cell Res., 22, 455-475.

Moscona, A. (1961b): Nature, 190, 408-409.

Moscona, A. (1961c): Scient. Amer., 205, 142-162.

Moscona, A. (1962): J. Cellular Comp. Physiol., Suppl. 1, 65-80. 
Steinberg, M. S. (1962a): Exptl. Cell Res., 28, 1-10.

Steinberg, M. S. (1962b): Proc. Natl. Acad. Sci. U. S., 48, 1577-1582.

Steinberg, M. S. (1962c): Science, 137, 762-763.

Steinberg, M. S. (1962d): Proc. Natl. Acad. Sci. U. S., 48, 1769-1782. 